\title{
ASS1 Gene Deficiency
}

National Cancer Institute

\section{Source}

National Cancer Institute. ASS1 Gene Deficiency. NCI Thesaurus. Code C138072.

A genetic finding indicating that low expression of the ASS1 gene has been detected in a sample. 